\title{
CORRECTION
}

\section{Correction to: Obstructive Sleep Apnea and Hypoxia in Geriatric Patients}

\author{
Aynur Yilmaz Avci ${ }^{1}$ (1) Suat Avci $^{2}$ (]
}

Published online: 22 September 2021

(c) Springer Nature Singapore Pte Ltd. 2021

\section{Correction to: Sleep and Vigilance}

https://doi.org/10.1007/s41782-021-00156-2

In the original article, the affiliations of the authors are published incorrectly. The corrections affiliations are given below.

Aynur Yilmaz Avci ${ }^{1,2}$, Suat Avci ${ }^{1,2}$ should be changed to Aynur Yilmaz Avci ${ }^{1}$, Suat Avci ${ }^{2}$.

The original article has been corrected.

Publisher's Note Springer Nature remains neutral with regard to jurisdictional claims in published maps and institutional affiliations.

The original article can be found online at https://doi.org/10.1007/ s41782-021-00156-2.

$\triangle$ Aynur Yilmaz Avci

aynuryilmazavci@gmail.com

1 Department of Neurology, Baskent University Faculty of Medicine, Ankara, Turkey

2 Department of Otolaryngology, Head and Neck Surgery, Baskent University Faculty of Medicine, Ankara, Turkey 